American Journal of Public administration
(ISSN:2641-4597)

\title{
Perception of Community Members on the provision of Low Cost Housing in Kwa-Dlangezwa Area, KwaZulu-Natal, South Africa
}

\section{Lindokuhle Muziwandile Mkhwanazi, Mfaniseni Wiseman Mbatha, Manqoba Khulekani Phakathi}

University of Zululand, South Africa

\begin{abstract}
The South African government of democracy have shown to prioritise the provision of low cost housing to poor communities. This paper critically investigates the perception of community members on the provision of low cost housing. The paper followed qualitative approach with an ethnographic research design and semi-structured interviews, as a result, the open ended questions were used as a tool for data collection. The snowball sampling was adopted as a procedure to sample the intended participants. The sample size of this paper was 36 participants and content analysis was used to analyse and categorise the data. The provision of low cost housing in South Africa was introduced with an intention to deal with racial inequalities created during apartheid period, while also addressing issues related to poor services delivery in local municipalities. Some of the indispensable facets of the findings expose that the local government is struggling to address the existence of bottlenecks in ensuring housing provision and the apparently cumulative demand of housing. The findings of the study found that the low cost housing beneficiaries were not involved during the processes of decision making and implementation phase of the projects. While political affiliation noted as an underlying factor that creates unfairness provision of low cost housing. Therefore, municipal officials through ward councillors and community leaders should play an essential role to facilitate smooth provision of low cost housing, while ensuring that the intervention reaches intended beneficiaries without unnecessary backlogs.
\end{abstract}

*Correspondence to Author:

Lindokuhle Muziwandile Mkhwanazi University of Zululand, South Africa

How to cite this article:

Lindokuhle Muziwandile Mkhwanazi, Mfaniseni Wiseman Mbatha, Manqoba Khulekani Phakathi. Perception of Community Members on the provision of Low Cost Housing in Kwa-Dlangezwa Area, KwaZulu-Natal, South Africa. American Journal of Public administration, $2019,1: 7$.

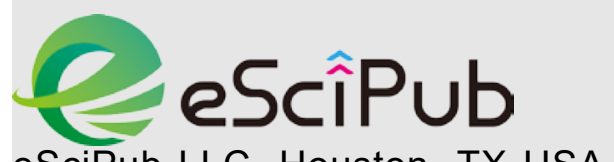
eSciPub LLC, Houston, TX USA. Website: https://escipub.com/

Keywords: Low Cost Housing, Service Delivery, Poor People, South Africa 


\section{INTRODUCTION}

The South African constitution recognises housing as a pivotal basic human need and right that needs to be attended to. Housing is also regarded as an efficacious indicator on how the issues of poverty have been eliminated within the country. As a result, the provision of low cost housing remains the priority for postapartheid South African government. Goebel (2007) concurs that South African government has introduced low cost housing to fight against poor service delivery by municipalities, while addressing the issue of racial inequalities caused by apartheid regime. The introduction of low cost housing came with a significant aim to replace shacks among unemployed families, including those who jointly earn less than R3500 per month. However, the government is struggling to address the existing bottlenecks or stumbling blogs within low cost housing context, including failure to meet an overwhelming demand of low cost houses, more specifically in reference to people from disadvantaged background. Sikota (2015) stresses out that some poor communities have taken the matter to the street with an intention to submit their indignations and frustrations on the slow progress of public services, particularly low cost housing provision.

Hence, the provision of low cost housing to poor communities has turned out to be a political subject in South Africa. Despite the intervention by government to address the growing demand for housing, low cost housing delivery still remains the constrain to poor communities. Ziblim, Sumeghy, and Cartwright (2013) provide a rough estimate that more than 2 million of South African households still reside under the extremely perilous conditions, which most of the time occurs within informal settlements. These households lack access to basic services that are required to be installed in a house. This includes but not limited to the availability of portable water, and electricity. The majority of poor and low income households are unable to access land, since proper and productive land is market oriented and poor people does not afford to buy it.

Therefore, it is very important to explore the perception of community members on low cost housing in South Africa. This paper seeks to cover two objectives, which is to investigate the provision of low-cost housing and also to explore challenges associated with low-cost housing in South Africa, Kwa-Dlangezwa in particular. The findings from this paper are intended to cater meaningful contribution to be body of knowledge. This shall happen through demonstrating the importance of prioritizing the provision of low cost housing to poor people and enhance their standard of living. The results discovered from this paper will further play an important role in understanding the value of ensuring effective provision of low cost housing to fight against poor service delivery in South Africa. Apart from the introduction of this study, the following section begins with the literature review that is considered to relate towards the provision of low cost housing. The other section of the paper presents methodology and material that has been used to conduct this paper, followed by a section that adheres on presenting results and discussion of the findings. The paper is culminated by presenting the conclusion and recommendations.

\section{LITERATURE REVIEW}

\section{General overview of Low cost housing in South Africa}

Patnaikuni (2012) states that low cost housing is a project that provides affordable houses to poor people and low income earners. Chaskalson (2017) concurs that the projects of low cost housing are underpinned within the Reconstruction Development Programmes (RDP) introduced by South African government for poor people with a joint income of R3500 and below. Low cost houses previously entailed the simple single story structures, which are big 
in size and have a capacity to accommodate a single family (Greyling, 2009). In addition, the RDP is not only focusing on providing low cost houses, but it also adheres on the renovation and reconstruction of currently existing buildings. The renovation and reconstruction is regarded as the cheapest option, since the super structures of the buildings are already in existence. However, the cost of that particular building which is ready for renovation depends on it situation and conditions. Sabela (2014) points out that low cost housing in South Africa has been appropriately positioned in terms of having an access to economic opportunities, educational, health and other facilities.

Khaki (2009) states that the South African government has built thousands of houses through RDP since the year of 1994. The aim of low cost housing is to assist poor people from squatter camps and houses that are no longer in adequate conditions. In addition, the living standard for families who reside in squatter camps is low, as they afford only basic needs. Scholars such as Crabbe and Close (2016) put forward that the South African squatter camps have high percentage of crime rates. Hence, such conditions of livings can strangely causes the epidemic of disease and other issues that can put health of people in risk. Chaskalson (2017) confirms that the provision of low cost housing through RDP programme was anticipated to ensure better security towards reducing crime rate and grants protection against environmental factors.

\section{Living conditions in low-cost housing settlements}

Toxopeüs (2019) states that adequate shelters with sanitation and access to safe water are considered to have enough elements of community health. Nevertheless, Yglesias (2015) stresses out that most developing countries are experiencing lack of suitable and affordable provision of low cost housing. While Govender, Barnes, and Pieper (2011) note that the process of urbanisation in the form of rural- urban drift has negatively affected smooth facilitation of low cost housing provision in South Africa. Such process contributes to low cost housing bottleneck and to the pretentiousness major constraints in phases of public health, housing, education and economics. Govender (2011) states that the beneficiaries of low cost housing are selected from groups of people who live in informal settlements nearby towns and cities. However, the provision of subsidised houses was in utmost cases not accompanied by an enhancement in terms of income.

Thus, Marutlulle (2017) states that beneficiaries of low cost houses end up misuse some few resources available in area of their houses, such as space in the backyard. In addition, these beneficiaries grant permission to other poor people to build sharks to be rented out for income generation. Breysse et al. (2004) state that the significance of adequate houses to ensure maintenance of health environment is regarded as one of the basic beliefs of public health. This is due to the point that there is lack of evidence on whether the provision of new low cost housing to poor people is going to enhance their health. In this regard, Govender et al. (2011) express that the lack of evidence on what seems to be self-evident can be accredited to many factors and multifaceted nature of low cost housing that accompanying poverty and the degradation of environment.

\section{Challenges on the provision of low cost housing}

Poor and insufficient budget for low cost housing: the study of Le Roux (2011) reveals that the provision of low cost housing is currently experiencing the lack and rough flow of funds, unbalanced subsidisation which is poorly coordinated. Hence, the value of the subsidy is failing to keep pace to be in line with the inflation, while there is the complex mechanism pertaining the approval of and payout of subsidy. The provision of low cost housing is also obstructed by issues, includes 
but not limited to target and affords the continuing charges of subsidized housing. Mbatha (2018) states that they are many challenges that hinder the provision of low cost housing in South Africa. Furthermore, it is also recognised that there is an existence of grey gap, which can be referred to households who earns between R1500 and 3500 every month. While on the other hand, Le Roux (2011) mentions that there is lack of community based delivery and minor contemplation set towards ensuring integrated development for low cost housing.

Poor participation of stakeholders: the study conducted by Sabela (2014) shows that stakeholders are key role players to facilitate all processes and necessary procedures of low cost housing provision. These stakeholders includes Non-Profit Organisations; CommunityBased Organisations; and Non-Governmental Organisations. Such stakeholders were and continue to be necessary in the provision of low cost housing. Govender et al. (2011) stress out that some low cost housing projects provided to beneficiaries were simply credit linked and their finances were organised by developers. Therefore, low cost housing beneficiaries were not involved during decision making processes and implementation phase of the projects. This indicates an impression that low cost housing beneficiaries are unable to participate in their own development.

Political apprehension: Sikota (2015) puts forward that there is an existence of different political deliberations affiliated in the provision of low cost housing in South Africa. This provides a sigma in processes of low cost housing, as some intended beneficiaries insist claiming their right to sufficient housing. This has been witnessed through service delivery protest in many issues related to the provision of low cost housing and other public services. The political apprehension on the provision of low cost housing also includes the issue of housing waiting list. Hence, these issues have generated a lot of debates about who can benefits from the provision of housing by the State, and it has further created tension amongst communities (Sikota, 2015). Another issue related to political apprehension is corruption, which is widespread from local to national spheres of government.

\section{Policy implication on the provision of low cost housing}

In 1994, the South African government has introduced the Reconstruction and Development Programme (RDP) as a strategy for low cost housing provision. However, this housing policy have failed in a number of respects (Govender, Barnes, and Pieper, 2011) and was successively changed through an adoption of Breaking New Ground in 2004. The main focus of the Breaking New Ground is to promote human settlement growth that is workable to fast track low cost housing delivery, while also concentrating on ensuring quality formed structures (Sabela, 2014). In addition, this plan also target to eliminate poverty, create jobs opportunities, and generate wealth while simultaneously improving economic growth. The Breaking New Ground is mostly regarded as a turnaround strategy in housing provision nationwide (Le roux, 2011).

This is due to the point that this housing strategy is further informed by the Global Plan of Action, the Habit Agenda and also Millennium Development Goals. Therefore, the Breaking New Ground housing strategy adheres more on the following objectives: improving the low cost housing product, improving the setting of new housing projects, encouraging densification and assimilation, assisting urban renewal and inner city regeneration, developing social and economic infrastructure (Sabela, 2014). Furthermore, this housing strategy serves as a response on the growing population rates, households and unemployment rates which results to the existence of urbanisation.

\section{Methodology and Materials}

AJPA: https://escipub.com/american-journal-of-public-administration/ 
Research approach and design: this paper adopted qualitative approach with ethnographic research design in order to comprehend the perceptions of community members on the provision of low cost housing in KwaDlangezwa Area. Astalin (2013) put forward that ethnographic research design assist in undertaking social sciences which mainly studies the origin and social interactions of human beings. While Mouton (1996) states that qualitative research consist of a wealth and rich descriptive data, which is collected through the use of semi structured interviews.

Sampling method and size: the data was collected from participants who are recipients of low cost housing within the study area. These community members have voluntarily agreed to participate during all the phases of conducting interviews that took place within variety communities in kwa-Dlangezwa area. These participants were sampled through the use of snowball sampling. Maree (2007) explained that the snowball sampling can be used during the time where it is very hard to find population or where the interest of researcher is in an interconnected group of people. Therefore, the researchers employed this method to identify low-cost housing recipients who are not easily found. Hence, the researchers asked the visible participates to identify the location of concealed recipients to be interviewed, especial those who reside in the middle of the forest. The researchers have sampled only people who live in low-cost housing within the area of kwaDlangezwa. Researchers visited four communities in kwa-Dlangezwa area namely, Khandisa, Nkonjane, eDanyini and uMhlathuze community in order to successful complete the semi-structured interviews. Hence, the sample size of the study consisted a total of 36 participants, whereby 27 participants were females and the other 9 participants were males respectively.

Data collection and Analysis: this paper used semi-structured interviews with open ended questions as a tool for data collection. This method of data collection have granted freedom to participants as they were able to express their perception through the use of their own terms. In addition, Kallio (2016) states that the open ended questions grants participants with the ability to provide more information without any limitations, and researchers were also able to raised follow up questions. The semistructured interviews were employed to collect primary data from thirty six (36) participants. Furthermore, content analysis was employed to analyse and categorise qualitative data on the bases of themes derived from the two objectives of the paper that was conducted through semi-structured interviews. Hence, content analysis allowed the researcher to read the interviews carefully; afterwards the researcher was able to identify and formulate several topics.

\section{Results and discussions}

Criteria used in selection of low cost housing: The majority of participants stated that they undertake the process of applying for low cost housing through submission of required documents. These documents include certified identity copies, and all birth certificates of children, submission was made to ward councillors. Participants further explained that the ward councillors prioritised their applications, as they were living in collapsing and unstable houses. Jackson (2015) emphasises that all South Africans have a right to adequate housing mandated within the constitution, with the state expected to grant reasonable support and resources. Other participants mentioned that they applied for low cost housing through tradition court. Application of low cost housing through traditional court was mostly undertaken by orphans, and the tradition court took the applications to ward councillors for review and consideration. Therefore, ward councillors are always obligated to call community meetings, 
with an intention to inform the applicants about the progress of their applications.

Procedures used in accessing low cost housing: The majority of participants stated that the provision of low cost housing has a fair procedure within the study area. This is because the majority of participants who applied for low cost houses have received them. Participants further explained that the provision of low cost housing had two phases and people who did not receive their low cost housing in a first phase were carted for, during the second phase. However, the minority of participants stated that the procedures used on the provision of low cost housing were unfair. This is due to the point that some of the community members who were extremely vulnerable and deserving to be granted houses did not receive any assistance. These participants viewed political affiliation as a factor that creates unfairness on the distribution of low cost housing. This is because some of these low cost houses are owned by people who already have proper houses, while there are vulnerable people who are suffering, but they did not receive any of low cost houses. The root cause is that leaders who serve the needs of poor communities prioritise their selfinterest before people's interest.

\section{Infrastructural conditions in low cost} housing: the majority of participants have indicated being dissatisfied about conditions of infrastructural services. This is because there are struggling to access roads due to the poor maintenance that does not allow public transport to pick and drop them in their homes. Participants also mentioned that clinics are allocated far away from their homes, which compel them to hire expensive transports that will take them to clinics. Other participants complained about the unavailability of shopping malls and centres, as their areas are dominated by spaza shops which provide insufficient products to be purchased by community members. The area was also reported to have limited sport fields, as a result, community members are forced to utilise sport grounds of the University of Zululand as located in proximity. However, the minority of participants stated that they are privileged to have access towards other infrastructural services, this includes but not limited to effective roads links to the public clinic, schools and police station.

The living conditions in low cost housing: the majority of participants have indicated that their living conditions in low cost housing are no longer bad as compared to the houses they were using before. This is due to the fact that they have access to electricity and rooms are strong enough to cope with heavy rains. While the minority of participants have shown to be worried about sizes of their low cost houses since they have many children, as a result, the rooms are too small to accommodate all members of the family. Therefore, other family members are forced to use collapsing old shacks in the yard. Other participants are concerned that their low cost houses have no ceiling board, no ventilators, and also have no bathrooms and toilets. As a result, they experience water leakage which destroys their furniture, and worse the beneficiaries were told to use their own money for their low cost houses' upgrades and repairs.

Challenges on the provision of low cost housing: The majority of participants have reported numerous issues with regards to the provision of low cost housing. These issues include but not limited to the delays in starting to build houses to beneficiary's areas of choice, of which such delays are claimed to be caused by local municipality. In some cases the delays are caused by shortage of suitable land that can be used to build low cost houses, since most areas are dominated by wet land. Participants further mentioned that some community members experienced delays to receive their low cost houses because their family members who applied for low cost housing passed away. The issue of poor 
consultation among community members and the municipality was noted to hinder the process of low cost housing provision. The participants indicated that the municipality does not involve them in decision making. Rather, they simply provide service delivery without any consultation with communities in order to get their views about the kind of development they need. The participants made an example that the municipality built two toilets per households apparently they were initiating the phase two of sanitation project. However, those toilets were not very important as compare to the needs of having roads and access to water which was regarded as a serious problem within these communities.

\section{Conclusion and recommendations}

Conclusion: This paper investigated the provision of low cost housing to poor communities, while also exploring challenges associated with low cost housing in KwaDlangezwa area. The findings of this paper indicated that there was proper procedure used in accessing low cost housing by community members of the study area. However, other participants have stipulated that the procedure was not fair enough in catering for all low cost housing applicants. This is because other poorest low cost housing' applicants ended up not granted houses, worse, these individuals were considered as being extremely vulnerable.. On the other hand some participants experienced delays in receiving their low cost houses, due to shortage of suitable land that can be used to build sustainable houses. The findings further revealed that low cost housing beneficiaries were struggling to access most amenities such as roads and sport grounds. While poor consultation between community members and the municipality shown to constrain proper service delivery with specific reference to low cost housing provision within the study area.

Recommendations: This paper put forward as a recommendation that the municipal officials through ward councillors and community leaders should work in collaboration to make sure that the provision of low cost housing is facilitated fairly and it reaches intended beneficiaries. This should be done in a well classified manner, whereby the most needy and vulnerable community members are prioritised in service delivery general, and low cost housing provision in particular. Therefore, this recommendation can be attained through proper consultation among the key stakeholders such as municipal officials, community members as well as traditional leaders. Such engagements among aforementioned key stakeholders will assist to eliminate duplication of same services delivery as in the case of sanitation project in kwaDlangezwa area as delineated earlier on. Finally, it is also recommended that low cost housing designers and engineers must have adequate skills and expertise when structuring the design plans for low cost housing so that they will be able to accommodate all necessary housing features, while avoiding cutting corners. As it compromises the quality of houses in attempt to increase the quantity which in many cases these houses collapse in a long term. . The key stakeholders should also take into consideration the importance of conducive environment in low cost housing, which comply with endorsed health standards of the country.

\section{References}

1. Astalin, P.K., 2013. Qualitative research designs: A conceptual framework. International Journal of Social Science and Interdisciplinary Research, 2(1), pp.118-124.

2. Breysse, P., Farr, N., Galke, W., Lanphear, B., Morley, R. and Bergofsky, L., 2004. The relationship between housing and health: children at risk. Environmental health perspectives, 112(15), pp.1583-1588.

3. Chaskalson, J., 2017. Everything you need to know about government housing. GroundUp. Available at: https://www.groundup.org.za/article/everythingyou-need-know-about-government-housing/ (Accessed 20 April 2019) 
4. Crabbe, H., and Close, R., 2016. The health problems associated with poor housing and home conditions, inadequate water supplies, flooding, poor sanitation and water pollution. Health Knowledge. Available at: https://www.healthknowledge.org.uk/publichealth-textbook/disease-causation-diagnostic/2fenvironment/health-problems-poor-housing (accessed 28 April 2019)

5. Goebel, A., 2007. Sustainable urban development? Low-cost housing challenges in South Africa. Habitat International, 31(3-4), pp.291-302.

6. Govender, T., 2011. The health and sanitation status of specific low-cost housing communities as contrasted with those occupying backyard dwellings in the City of Cape Town, South Africa. PhD. Stellenbosch University. Available at: http://scholar.sun.ac.za/handle/10019.1/17992 (Accessed 03 May 2019)

7. Govender, T., Barnes, J.M. and Pieper, C.H., 2011. Housing conditions, sanitation status and associated health risks in selected subsidized low-cost housing settlements in Cape Town, South Africa. Habitat International, 35(2), pp.335342.

8. Jackson, M., 2015. South Africa's low-cost housing: constraints and opportunities. UrbanAfrica.Net. Available at: https://www.urbanafrica.net/urbanvoices/constraints-and-opportunities-in-southafrican-low-cost-housing/ (Accessed 11 May 2019)

9. Khaki, I., 2009. Housing in South Africa: the challenge to provide sustainable, integrated, affordable housing (Doctoral dissertation, Stellenbosch: University of Stellenbosch).

10. Le Roux, F.E., 2011. The provision of low-cost housing in South Africa: a wicked problem with a systems theory solution. Stellenbosch University. Unpublished Masters Dissertation. Available at: http://citeseerx.ist.psu.edu/viewdoc/download?do $\mathrm{i}=10.1 \cdot 1.880 .3846 \& \mathrm{rep}=\mathrm{rep} 1 \&$ type $=$ pdf (Accessed 06 May 2019)

11. Maharaj, N., 2012. Governance and service delivery a case-study of sanitation in Inanda, Durban. PhD. University of KwaZulu-Natal. Available at: https://researchspace.ukzn.ac.za/xmlui/bitstream /handle/10413/10059/Maharaj_Nuthan_2012.pdf ?sequence $=1$ \&isAllowed $=y$ (Accessed 06 May 2019)

12. Maree, K., 2007. First steps in research. Van Schaik Publishers.
13. Marutlulle, N.K., 2017. Causes of informal settlements in Ekurhuleni Metropolitan Municipality: An exploration. Africa's Public Service Delivery and Performance Review, 5(1), pp.1-11.

14. Mbatha, S., 2018. Informal transactions of low income houses in South Africa: a case study of eThekwini Municipality. PhD. University of Stuttgart. Available at: https://elib.unistuttgart.de/bitstream/11682/9816/1/Sandile_Mb atha\%202018.pdf (Accessed 06 May 2019)

15. Mouton, J., 1996. Understanding Social Research, Van Schaik Publishers: Pretoria.

16. Patnaikuni, I., 2012. Sustainable Low Cost Housing Construction method. $5^{\text {th }}$ SASTech International Conference: Research, Development and Practice in Structural Engineering and Construction. Available at: https://www.researchgate.net/publication/268463 904_Sustainable_Low_Cost_Housing_Constructi on_for_a_Better_World (Accessed 21 April 2019)

17. Sabela, P.T., 2014. Towards an alternative development approach to low cost housing delivery in KwaZulu-Natal province. PhD. University of Zululand. Available at: https://docplayer.net/25079908-Towards-analternative-development-approach-to-low-costhousing-delivery-in-kwazulu-natal-provinceprimrose-thandekile-sabela-2014.html (Accessed 21 April 2019)

18. Sikota, Z., 2015. No meaningful participation without effective representation: the case of the Niall Mellon Housing Project in Imizamo Yethu, Hout Bay. Master's Dissertation. University of the Western Cape. Available at: https://etd.uwc.ac.za/bitstream/handle/11394/497 9/Sikota_z_ma_ems_2015.pdf?sequence=1\&isAl lowed $=y$ [Accessed 11 April 2019]

19. Sikota, Z., 2015. No meaningful participation without effective representation: the case of the Niall Mellon Housing Project in Imizamo Yethu, Hout Bay. Master's Degree. University of the Western Cape. Available at: https://etd.uwc.ac.za/bitstream/handle/11394/497 9/Sikota_z_ma_ems_2015.pdf?sequence $=1$ (Accessed 06 May 2019)

20. Toxopeüs, M., 2019. The state of sanitation and wastewater treatment services in South Africa. Helen Suzman Foundation. Available at: https://hsf.org.za/publications/hsf-briefs/the-stateof-sanitation-and-wastewater-treatment-servicesin-south-africa (Accessed 05 May 2019)

21. Yglesias, M., 2015. Everything you need to know about the affordable housing debate. Vox Media. Available at: 
https://www.vox.com/2014/4/10/18076868/afford able-housing-explained (Accessed 03 May 2019)

22. Ziblim, A., Sumeghy, M.G. and Cartwright, A., 2013. The dynamics of informal settlements upgrading in South Africa. Habitat International, 37, pp.316-334.

23. Ziblim, A., Sumeghy, M.G. and Cartwright, A., 2013. The dynamics of informal settlements upgrading in South Africa. Habitat International, 37, pp.316-334.

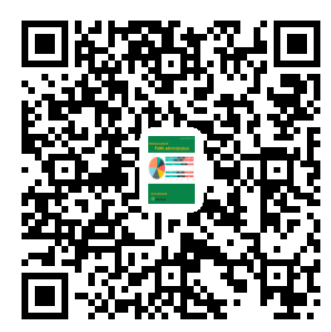

